\title{
CHARACTERIZATION OF TEMPORAL RAINFALL DISTRIBUTION IN FLORIANÓPOLIS, SANTA CATARINA, BRAZIL
}

\author{
BACK, Álvaro José - alvarojoseback@gmail.com \\ Universidade do Extremo Sul Catarinense / UNESC \\ Empresa de Pesquisa Agropecuária e Extensão Rural de Santa Catarina / \\ EPAGRI
}

RODRIGUES, Maria Laura Guimarães - laura@epagri.sc.gov.br

Empresa de Pesquisa Agropecuária e Extensão Rural de Santa Catarina /

EPAGRI

Submetido em: 28/04/2020

Aceito para publicação em: 05/02/2021

Publicado em: 06/04/2021

DOI: http://dx.doi.org/10.5380/abclima.v28i0.73260

\begin{abstract}
Temporal rainfall distribution is an important information for the preparation of the design hyetograph, directly influencing peak flow. This study analyzes the temporal rainfall distribution of Florianópolis city. We used rainfall data from 1986 to 2012 obtained from the Brazilian National Meteorological Institute (INMET). Heavy rainfall events were classified and individualized, and intensities were determined at each $5 \%$ interval of the duration. Rainfall was classified in Huff quartiles and identified by season and duration. Rainfall accumulation curves in the 10-90 percentiles were determined as well as $50 \%$ probability curves for each season and duration. The results showed that type I rainfall is the most frequent and that summer rains have a more anticipated pattern. Important differences were found between rainfall durations. The advance coefficient varies with rainfall duration, and averaged 0.389.
\end{abstract}

KEYWORDS: Hyetograph; drainage; advance coefficient; design rainfall; Chicago method.

CARACTERIZAÇÃO DA DISTRIBUIÇÃO TEMPORAL DE CHUVAS PARA FLORIANÓPOLIS, SANTA CATARINA, BRASIL

RESUMO: A distribuição temporal da chuva é uma informação importante para a elaboração do hietograma de projeto, influenciando diretamente a vazão de pico. 0 trabalho teve como objetivo analisar a distribuição temporal de chuvas de Florianópolis. Foram usados dados pluviográficos do período de 1986 a 2012 da estação meteorológica do Instituto Nacional de Meteorologia (INMET). As chuvas intensas foram classificadas e individualizadas, determinando-se as intensidades a cada intervalo de $5 \%$ da duração. As chuvas foram classificadas nos quartis de Huff, e identificadas por estação do ano e faixa de duração. Foram estabelecidas as curvas acumuladas nos percentis de 10 a $90 \%$ e também as curvas com $50 \%$ de probabilidades para cada estação do ano e faixa de duração. Os resultados mostraram que as chuvas do tipo I são as mais frequentes e que as chuvas de verão têm padrão mais antecipado que as demais estações. Foram constatadas diferenças importantes ente as faixas de duração. O coeficiente de avanço varia com a faixa de duração e apresentou valor médio de 0,389.

PALAVRAS-CHAVE: Hietograma; drenagem; coeficiente de avanço; chuva de projeto; método Chicago.

\section{INTRODUCTION}

Drainage projects are usually carried out in sites with measured data of extreme flows. In this context, hydrological modeling is used to estimate flows and/or drainage volume (ABREU et al., 2017). This modeling requires determining the design rainfall, which is characterized by rainfall intensity, 
duration, frequency, and distribution over time, thus defining the design hyetograph.

Rainfall Intensity-Duration-Frequency relationships can be determined from the analysis of local data, and are generally established by IDF equations. There is a large number of studies, conducted in Brazil and abroad, determining IDF equations (PEREIRA et al., 2017; EL-SAYED, 2018; DIAS and PENNER, 2019).

Temporal rainfall distribution, which defines the shape of the hyetograph, is an important input parameter in the rainfall-flow models used in the design of hydraulic works (CHOI et al., 2014; ABREU et al., 2018). Canholi (2005) points out that temporal rainfall distribution comprises a major problem for the hydrologist, since for each distribution there are different hydrographs. Moreover, the São Paulo Rainwater Drainage and Management Manual (São Paulo, 2012) highlights that the type of temporal distribution of the design rainfall and the fixing of the duration are subject to several methodological guidelines, resulting in maximum discharges and flood volumes that can be quite disparate.

The influence of the pattern of temporal rainfall distribution on soil erosion is evidenced in several studies (SANTOS and MONTENEGRO, 2012; EVANGELISTA et al., 2016; PAN et al., 2017; BEZAK et al., 2018; NA and YOO, 2018; BALBASTRE-SOLDEVILA et al., 2019). Monteiro and Kobiyama (2014) showed that different patterns of temporal rainfall distribution resulted in a relevant variation in peak flow in the flooded zone. Abreu et al. (2018) showed that changing the method of temporal rainfall distribution led to differences of up to $46 \%$ in peak flow and $57 \%$ in flood spots.

The literature points to several methods for determining design hyetographs. The most important ones define a standard curve of temporal distribution and a standard hyetograph shape. The temporal distribution curve method is more used, with the advantage of being based on the statistical analysis of observed rainfall patterns (PRODANOVIC and SIMONOVOC, 2004; YIN et al., 2016; EL-SAYED, 2018).

Using data from 261 rainfall events with minimum intensity of $12.7 \mathrm{~mm}$ and duration from 3 to 48 hours, Huff (1967) presented curves for the 10-90 percentiles, including median curves (50 percentile). To represent the various regions of the USA, the Natural Resources Conservation Service (NRCS, 1986) developed four synthetic distributions of 24-hour rainfall (I, IA, II, and III). This method was used in Atlas 14 to estimate the design rainfall for eleven different regions.

Among the methods that define the hyetograph shape, the alternating block method, the triangular hyetograph method, and the Chicago method stand out. These methods have the advantage of being used in conjunction with the IDF equation. However, some authors have criticized the choice of these methods, as they do not actually represent the patterns observed in historical rainfall events, besides not being based on local observations (PAN et al., 2017; BALBASTRE-SOLDEVILA et al., 2019). In this regard, the Chicago method (WEESAKUL et al., 2017) has the advantage of including the advance coefficient to establish the position of the peak time of the hyetograph (SILVEIRA, 2016). Canholi (2005) states that the Chicago method has been widely used, as it 
derives from local IDF relationships. The comparison of the maximum flow rates estimated from the Chicago method with observed data showed good agreement of this method with peak flow (WEESAKUL et al., 2017).

In Brazil, given the lack of local information on the temporal distribution of heavy rainfall, it is generally recommended to use uniform distribution or to adopt relationships obtained in other countries (CRUCIANI et al., 2002). Some authors point out similarities between rainfall events observed in Brazil and in the United States to indicate type II rainfall (MARCELLINI, 1993; TUCCI, 2012). Notwithstanding, studies conducted in several countries show that significant differences between temporal distribution curves justify the need for local information (AZLI and RAO, 2010; EWEA et al., 2016; GHASSABI et al., 12016; Yin et al, 2016; PAN et al., 2017; EL-SAYED, 2018).

This study analyzes the temporal variation of heavy rainfall in Florianópolis city, Santa Catarina State, and relates temporal distribution with rainfall duration and season. According to Herrmann et al. (2007), Florianópolis is among the cities of Santa Catarina State with the highest frequency of landslides due to flooding from heavy rainfall.

\section{MATERIALS AND METHODS}

Rainfall records from 1986 to 2012 of the meteorological station of Florianópolis - SC (Figure 1), belonging to the monitoring network of the National Institute of Meteorology (INMET), code 83897 (27060'25" S latitude, $48^{\circ} 62^{\prime} 03^{\prime \prime} \mathrm{W}$ longitude, altitude of $5 \mathrm{~m}$ ), were used. Although called Florianópolis, the station currently belongs to the Municipality of São José, bordering Florianopolis. According to the Köppen classification, the climate of the region is type Cfa (ALVARES et al., 2013), temperate, constantly humid, without dry season, with hot summer (average temperature of the hottest month $>22.0{ }^{\circ} \mathrm{C}$ ). According to Epagri (1999), the climate is mild mesothermal (temperature of the coldest month between 15.1 and $16.0{ }^{\circ} \mathrm{C}$ ). Total annual rainfall ranges from 1,270 to $1,600 \mathrm{~mm}$, with 140 to 158 total annual rainy days. Despite the good rainfall distribution throughout the year, the highest volumes occur in the summer, followed by the spring (NIMER, 1979; GRIMM, 1998). 

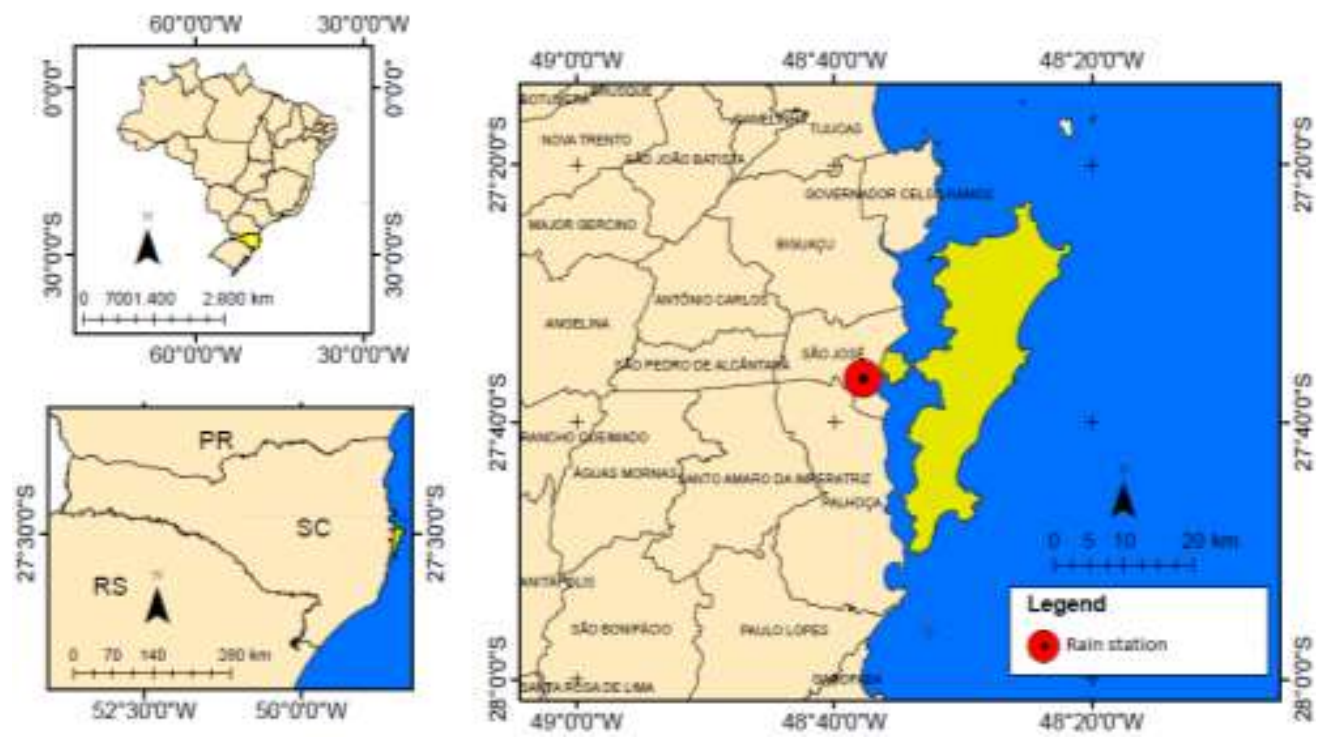

Figure 1 - Location of Florianópolis city (highlighted in yellow) and rain station (red point).

Rainfall records were digitized and stored in digital media. A Delphi routine was developed to manipulate data files and to select and classify heavy rainfall events. The procedure used can be described in six steps. The first step consisted of individualizing rainfall events using the criterion proposed by Wischmeier and Smith (1958). This criterion considers as an individual rainfall event that which is separated from the previous and the subsequent rainfall event for a minimum period of 6 hours without rainfall or with rainfall less than $1.0 \mathrm{~mm}$.

The end of the rainfall event was determined according to the criterion proposed by Powell et al. (2007), who established the intensity of $0.51 \mathrm{~mm} / \mathrm{h}$ to mark the end of rainfall. This criterion seeks to avoid very long events with little intensity.

The second step consisted of selecting heavy rainfall events to be analyzed. For that, we used the criterion established by Molin et al. (1996), which considers all rainfall events with intensity equal to or greater than the minimum rainfall (Rmin), estimated by:

$R_{\text {min }}=8.9914 D^{0.2466}$

where:

$\mathrm{R}_{\min }$ is the minimum rainfall ( $\mathrm{mm}$ );

$\mathrm{D}$ is the rainfall duration (minutes).

The third step consisted of determining rainfall height and intensity at each interval corresponding to $5 \%$ of the duration.

The fourth step was the classification of rainfall in four types, as defined by Huff (1967), determining rainfall amounts in the four quartiles of the duration. Thus, rainfall is classified as type I if the maximum rainfall height occurs in the first $25 \%$ of the total duration; type II if it occurs between 25 and 
$50 \%$ of the duration; type III between 50 and $75 \%$; and type IV in the last $25 \%$ of the total duration.

In the fifth step, accumulated rainfall percentages were obtained for the 10-90 percentiles (P10-P90). To obtain the rainfall values in the percentages defined above, linear interpolation of rainfall events was performed between the previous and the next percentile.

In the sixth step, we calculated the advance coefficient or peak factor $(r)$, determining the duration interval with the highest rainfall intensity, according to Table 1. For rainfall events with equal values of maximum intensity in two or more intervals, the advance coefficient was calculated by averaging the respective values.

Data analysis on temporal rainfall distribution and advance coefficient considered rainfall events by season and duration. Events were divided into durations of up to 6 hours, from 6 to 12 hours, from 12 to 24 hours, and longer than 24 hours. Seasons were defined as follows: January to March (summer); April to June (autumn); July to September (winter); and October to December (spring).

Table 1 - Rainfall intervals considered and their advance coefficient.

\begin{tabular}{rcc} 
Interval & Duration $(\%)$ & Advance coefficient $-r$ \\
\hline 1 & 5 & 0.025 \\
2 & 10 & 0.075 \\
3 & 15 & 0.125 \\
5 & 20 & 0.175 \\
5 & 25 & 0.225 \\
7 & 30 & 0.275 \\
8 & 35 & 0.325 \\
9 & 40 & 0.375 \\
10 & 55 & 0.425 \\
11 & 55 & 0.475 \\
12 & 60 & 0.525 \\
13 & 65 & 0.575 \\
14 & 70 & 0.625 \\
15 & 75 & 0.675 \\
16 & 80 & 0.725 \\
17 & 85 & 0.775 \\
18 & 90 & 0.825 \\
19 & 95 & 0.875 \\
20 & 100 & 0.925 \\
\hline & & 0.975
\end{tabular}

\section{RESULTS AND DISCUSSION}

According to the established criteria, 817 heavy rainfall events were selected in a period of 27 years. Type I rainfall predominated (39.9\%), followed, 
respectively, by type II (31.0\%), type III (15.7\%), and type IV rainfall $(13.5 \%)$ (Table 2). These results are in line with those observed for other locations in Santa Catarina State, such as Urussanga (BACK, 2011) and Chapecó (BACK et al., 2015). In Caçador city, type II rainfall predominated, followed by type III (BACK, 2012).

Table 2 - Relative frequency (\%) of heavy rainfall events by type and season in Florianópolis city (SC), in the period of 1986 to 2012.

\begin{tabular}{llllll}
\hline \multirow{2}{*}{ Type } & \multicolumn{5}{c}{ Season of the year } \\
\cline { 2 - 5 } & Summer & Autumn & Winter & Spring & \\
\hline I & 45.1 & 18.1 & 16.0 & 20.9 & 39.9 \\
II & 28.9 & 16.6 & 24.5 & 30.0 & 31.0 \\
III & 39.1 & 15.6 & 20.3 & 25.0 & 15.7 \\
IV & 18.2 & 20.0 & 25.5 & 36.4 & 13.5 \\
\hline Total & 35.5 & 17.5 & 20.6 & 26.4 & 100.0 \\
\hline
\end{tabular}

Using the criterion in which erosive rainfall events are classified according to the temporal distribution in advanced, intermediate, and delayed patterns, Back and Poleto (2019) showed that advanced patterns predominate in the eleven rainfall stations in Santa Catarina State. These stations are located in the municipalities of Chapecó, Urussanga, Campos Novos, Florianópolis, Videira, Caçador, Lages, Itá, São Miguel do Oeste, Ponte Serrada and Porto União.

Analyzing rainfall data from Pelotas city (RS), Molin et al. (1996) also observed the predominance of type I rainfall $(44.0 \%)$, followed by type III $(21.1 \%)$, type II $(19.8 \%)$, and type IV rainfall (15.1\%). Moreover, analyzing heavy rainfall data from Piracicaba city (SP), Sentelhas et al. (1998) and Cruciani et al. (2002) concluded that the most frequent rainfall events are those that occur in the first interval, which corresponds to the rainfall classified by Huff as type I.

In the conditions of western United States, Huff (1967) found a higher frequency $(36 \%)$ of type II rainfall, followed by type I $(30 \%)$, type III $(19 \%)$, and type IV rainfall (15\%). Due to the lack of studies in Brazil, some authors (TUCCI, 2012; MARCELLINI, 1994) justify the use of type II curves. The Municipal Secretariat of Urban Development of São Paulo (São Paulo, 2012) points out that drainage projects of urban watersheds mostly use data of rainfall events lasting two or three hours and with type I distribution according to the alternating block method or Huff method. Rainfall events lasting six hours and with type II distribution according to the alternating block method or Huff method are considered only for watersheds with areas greater than $100 \mathrm{~km}^{2}$. However, the data observed in Santa Catarina State point to the use of type I rainfall distribution. It is noteworthy that, although type III and type IV rainfall events were less frequent, they account for higher peak flows (DNIT, 2005).

Regarding seasonal variation, it appears that heavy rainfall events in Florianópolis city predominate in the summer $(35.5 \%)$, followed by spring $(26.4 \%)$, and are less frequent in the fall (17.5\%). Urussanga city, located on the coast south of the state, also showed a higher frequency (39.2\%) of rainfall events in the summer (BACK, 2001). Teixeira and Satyamurty (2007) observed that heavy rainfall events on the coast of Santa Catarina State are more frequent in the summer. 
In the Florianóplis region, Rodrigues et al. (2011) and Rodrigues (2015) found a greater number of heavy rainfall events between November and March (summer and spring), with February being the month with the highest number of records. According to these authors, such events are associated with the amount of moisture transported from the maritime area towards the Santa Catarina coast, which is also mentioned by Grimm (2009) as a factor contributing to heavy rainfall in the region. The passage of cold fronts is observed every month (RODRIGUES et al., 2004), which results in good annual rainfall distribution. Nevertheless, it is mainly in autumn and winter that these systems favor rainfall events on the coast, in general with more prolonged duration and less intensity than those observed during summer and spring. This rainfall characteristic justifies the more approximate frequency values in the autumn and winter months, among the four types in Table 2.

Type I and III rainfall events occur more frequently in the summer. In turn, type II and IV rainfall events occur more frequently in the spring. These frequencies stand out with values equal to and above $30 \%$. In summer and late spring, in addition to convective rains - of short duration and high intensity, associated with daytime heating -, Florianópolis has heavy rainfall events associated with the transport of maritime moisture, as studied by Rodrigues (2015) and Rodrigues and Ynoue (2016). These authors show a rainfall persistence in this region over hours, with high peaks that can reach 40 to 60 $\mathrm{mm} \mathrm{h}^{-1}$.

Analyzing the type and duration of heavy rainfall events (Table 3), it is observed that type I rainfall predominates in events less than 12 hours. For events lasting 12 to 24 hours, the frequency of type I rainfall is slightly higher than that of type II, both being high. Type II rainfall predominates in events over 24 hours, while the other types differ by less than $2 \%$. Similar results were obtained by Yin et al. (2016), who analyzed the temporal distribution of heavy rainfall based on data from 18 meteorological stations in China. The authors concluded that the frequencies of type I, II, III, and IV rainfall are, respectively, $38.3 \%, 26.8 \%, 22.4 \%$, and $12.5 \%$. They also identified that the proportion of type I rainfall was lower for long events, where the proportion of quartiles III and IV was higher, as observed for Florianópolis city (Table 3).

This finding corroborates the observations of Zahed Filho and Marcellini (1995), who state that for short rainfall events (less than ten hours), the hyetograph is usually represented by greater intensities in the first half of the duration, while in long rainfall events (more than ten hours) the hyetograph shows more uniform intensities.

Occhipinti (1989) makes a good differentiation between convective rainfall (from daytime heating) and frontal rainfall. According to the author, the first occurs in the form of localized rain showers, a name used to characterize its strong intensity in a short period, which usually occurs in the initial phase, diminishing in the following hours. In turn, frontal rainfall covers large areas and has a more uniform distribution over a long period. Cold fronts in southern Brazil move rapidly in the summer, initially causing heavy rain showers, followed by less intense rainfall (SEVERO, 1994; ANDRADE, 2005; CAVALCANTI and KOUSKY, 2009; ESCOBAR et al., 2016). Stationary systems acting over 24 hours generally produce less intense but continuous rainfall, which can result in 
high accumulations. According to Rodrigues et al. (2004), cold fronts move along the coast of Santa Catarina in an average period of 24 hours.

Another rainfall type characteristic of Florianópolis city is that associated with the transport of moisture from the ocean. According to Rodrigues (2015), this rainfall type generally persists between 12 and 24 hours. When its duration is longer (maximum of three days), rainfall is better distributed over time and with less high peaks, as seen in frontal systems.

Table 3 shows that, in the period less than 6 hours, heavy convective rainfall is the least frequent in Florianópolis city $(9.2 \%)$. Its frequencies do not differ much for the other duration classes, with values slightly higher for durations over 12 hours (32.2\% and 31.1\%). Type I and II rainfall, which account for $70 \%$ of the events, are much more frequent, respectively, in the intervals from 6 to 24 hours and above 12 hours, which represent both frontal and coastal rainfall.

Table 3- Relative frequency of heavy rainfall events by duration, as observed in Florianópolis city (SC) from 1986 to 2012.

\begin{tabular}{cccccc}
\hline & \multicolumn{5}{c}{ Duration classes } \\
\cline { 2 - 6 } Rainfall type & $<6 \mathrm{~h}$ & $6-12 \mathrm{~h}$ & $12-24 \mathrm{~h}$ & $>24 \mathrm{~h}$ & Total \\
\hline I & 5.9 & 13.7 & 12.5 & 7.8 & 39.9 \\
II & 1.8 & 7.2 & 10.5 & 11.4 & 31.0 \\
III & 0.9 & 3.9 & 4.8 & 6.1 & 15.7 \\
IV & 0.6 & 2.7 & 4.4 & 5.8 & 13.5 \\
\hline Total (\%) & 9.2 & 27.5 & 32.2 & 31.1 & 100.0 \\
\hline
\end{tabular}

Table 4 shows the relative frequencies of heavy rainfall by duration and season. It is observed that rainfall events less than 12 hours occur predominantly in the summer, characterizing convective rainfall $(<6 \mathrm{~h})$ or rapid passage of cold fronts (6-12h). Rainfall events over 12 hours are more homogeneously distributed between the seasons, with slightly lower values observed in the fall. Rainfall events over 12 hours predominate in all seasons except summer. These seasonal differences are more important for system management, urban drainage, and especially land drainage and cover. However, dimensioning considers maximum annual events, thus disregarding seasonality.

Table 4 - Frequency of heavy rainfall events by season and duration, as observed in Florianópolis city from 1986 to 2012.

\begin{tabular}{llllll}
\hline & \multicolumn{5}{l}{ Duration classes } \\
\cline { 2 - 6 } Season & $<6 \mathrm{~h}$ & $6-12 \mathrm{~h}$ & $12-24 \mathrm{~h}$ & $>24 \mathrm{~h}$ & Total \\
\hline Summer & 4.9 & 13.2 & 8.4 & 8.9 & 35.5 \\
Autumn & 1.2 & 3.5 & 7.0 & 5.8 & 17.5 \\
Winter & 1.2 & 3.9 & 7.5 & 8.0 & 20.6 \\
Spring & 1.8 & 6.9 & 9.3 & 8.4 & 26.4 \\
\hline Total & 9.2 & 27.5 & 32.2 & 31.1 & 100.0 \\
\hline
\end{tabular}

Figures 2 to 5 show the accumulated probability curves for heavy rainfall events classified as type I to IV, respectively. With these defined rainfall patterns, the designer can select one of the temporal distribution curves to determine rainfall and dimension the drainage project. The methodology 
normally used in drainage projects to obtain temporal rainfall distribution considers the curve with $50 \%$ probability (P50). Table 5 shows with these values for type I to IV rainfall.

Figure 6 shows temporal distribution curves by season. The rainfall pattern differs in the summer, with higher concentration at the beginning of the event. Thus, for a duration equivalent to $20 \%$ of the total duration, we have $32 \%$ of the total rainfall in the summer, and 17 to $20 \%$ of the total rainfall in the other seasons. For rainfall concentration, the other seasons differ by less than $5 \%$.

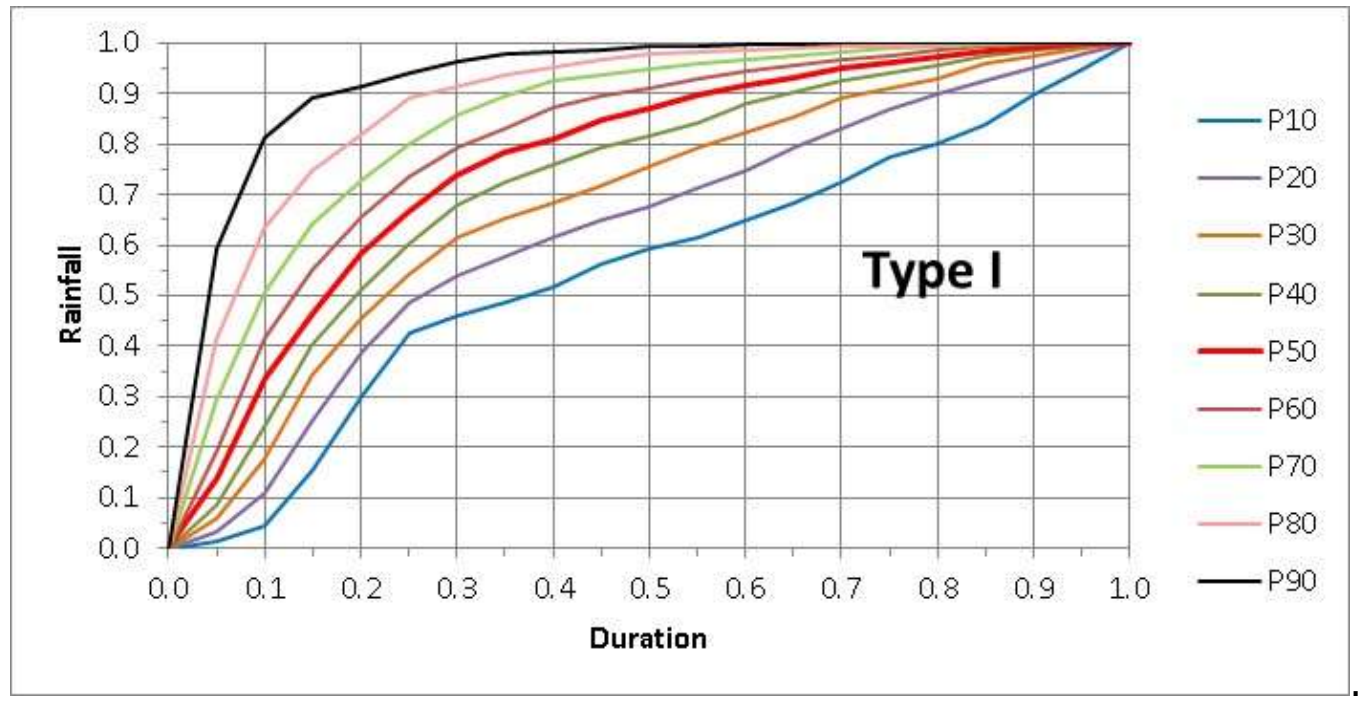

Figure 2 - Patterns of temporal distribution of type I rainfall for Florianópolis city (SC) from 1986 to 2012.

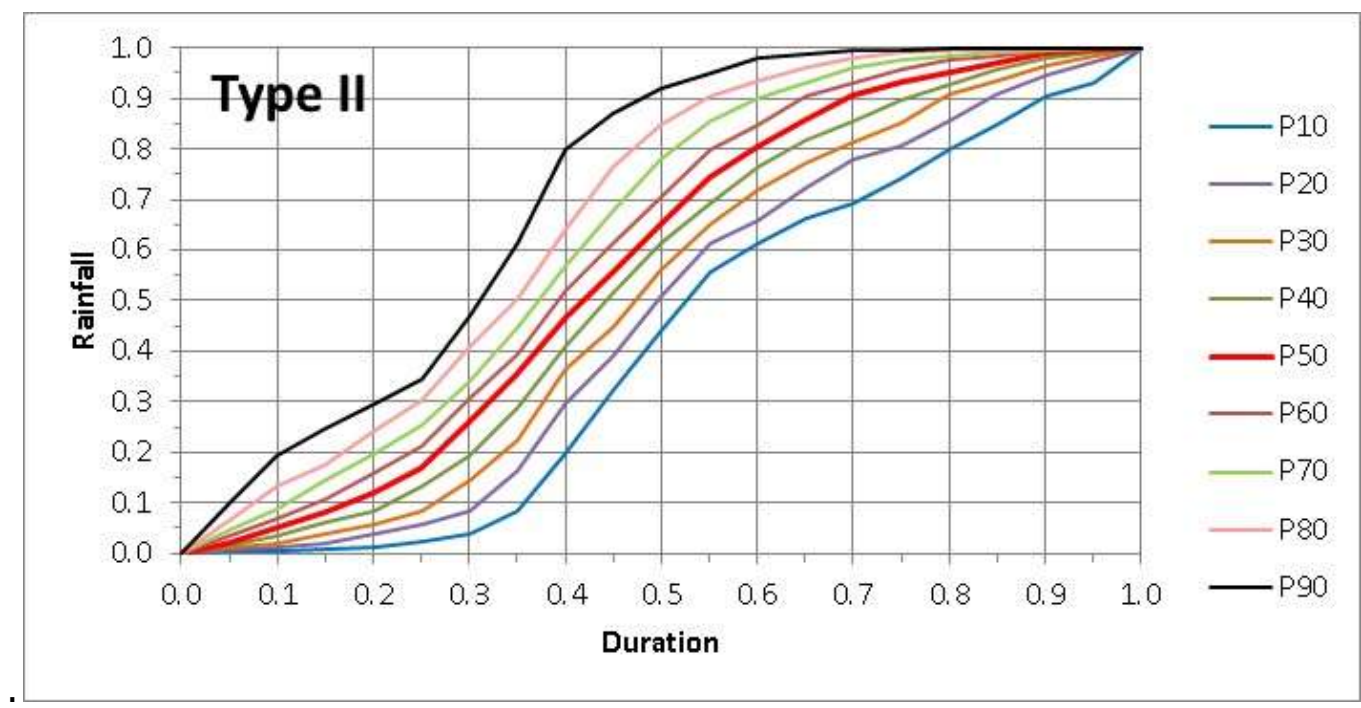

Figure 3 - Patterns of temporal distribution of type II rainfall for Florianópolis city (SC) from 1986 to 2012. 


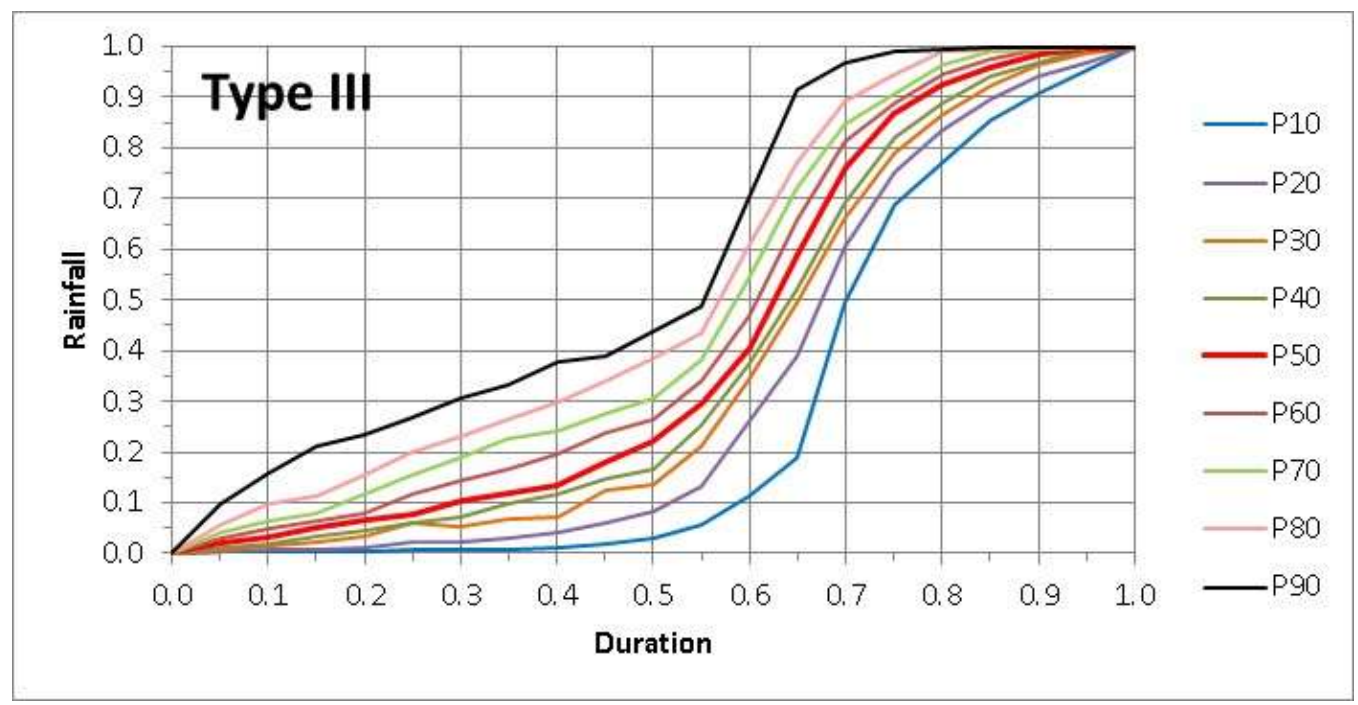

Figure 4 - Patterns of temporal distribution of type III rainfall for Florianópolis city (SC) from 1986 to 2012.

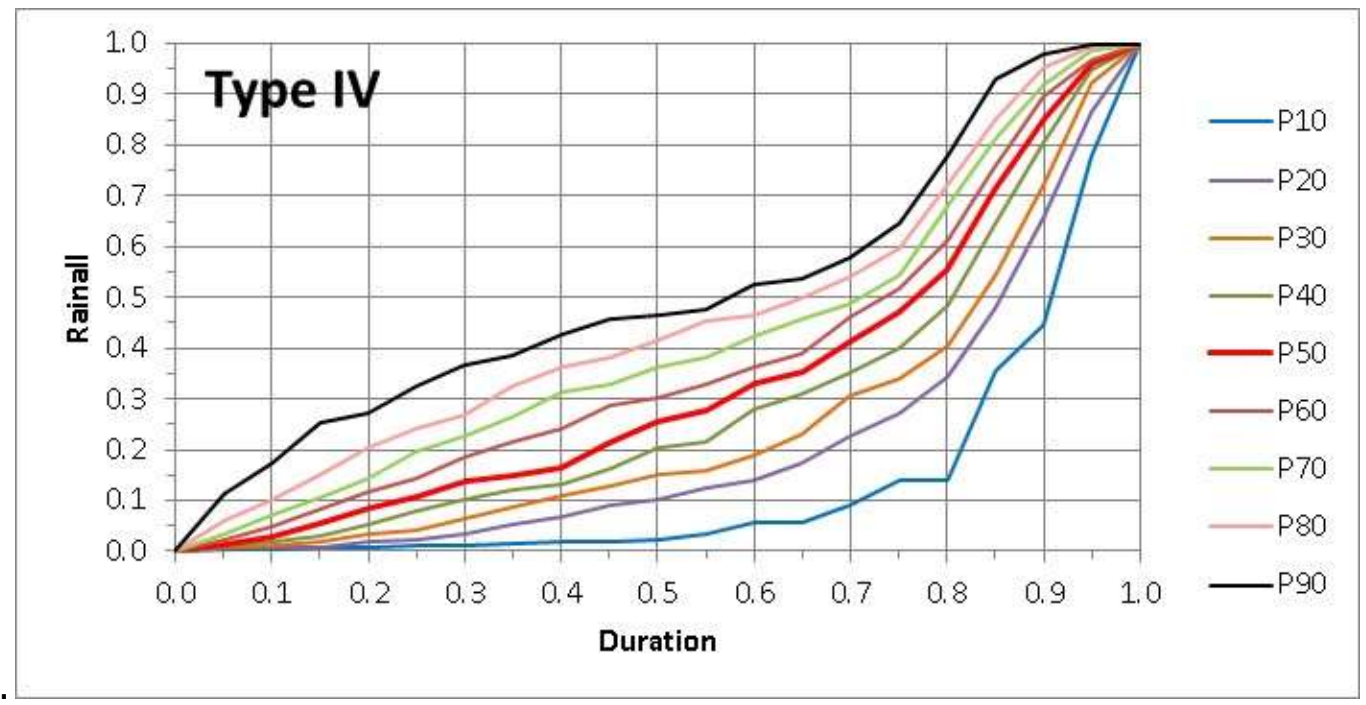

Figure 5 - Patterns of temporal distribution of type IV rainfall for Florianópolis city (SC) from 1986 to 2012. 


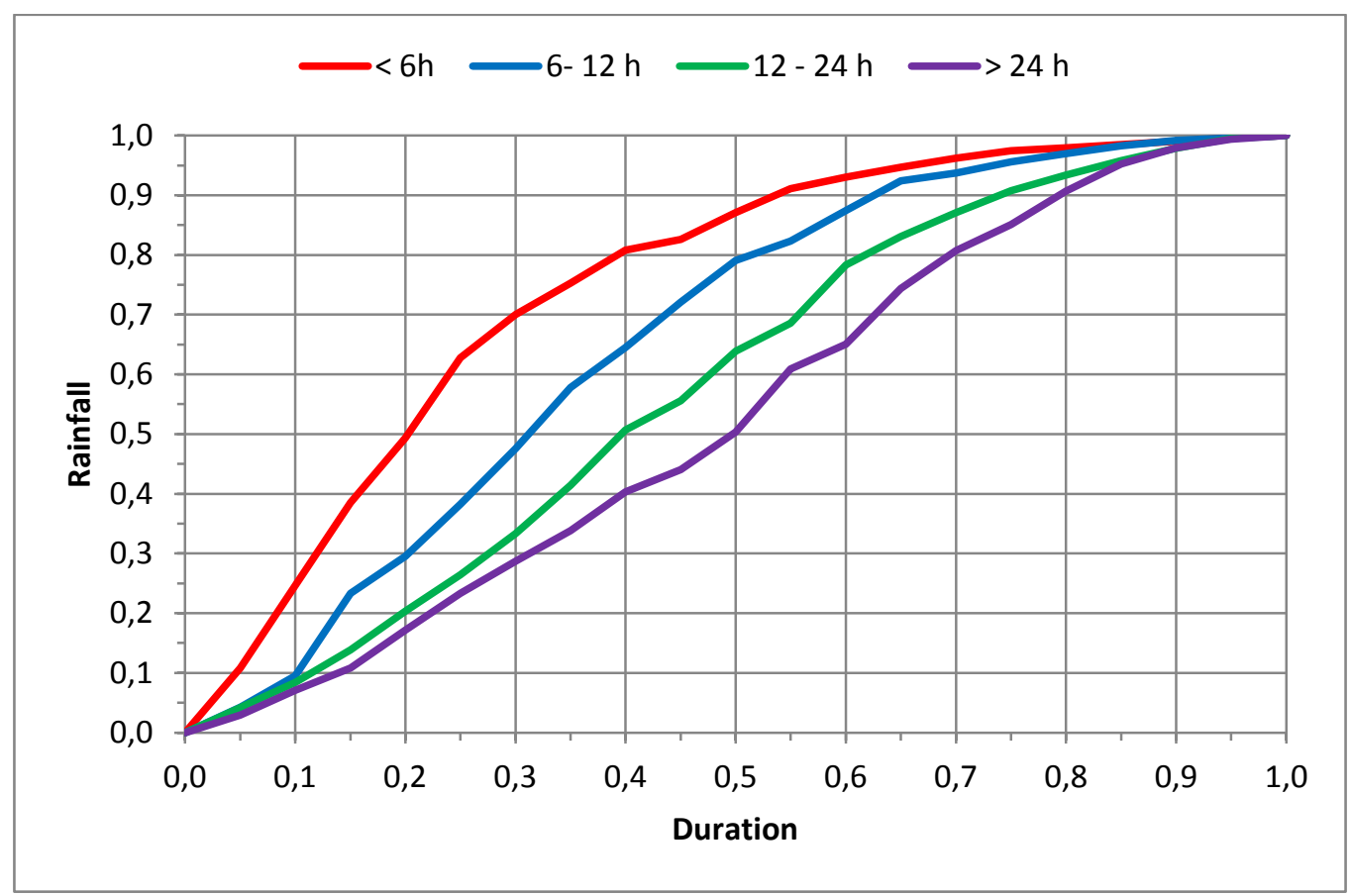

Figure 6 - Pattern of temporal rainfall distribution with $50 \%$ probability, by season, for Florianópolis city (SC) from 1986 to 2012.

Figure 7 shows heavy rainfall distribution curves by duration. Shorter rainfall events have a more advanced pattern, and distribution tends to be more uniform as the rainfall duration increases. For rainfall events less than 6 hours, the duration equivalent to $20 \%$ of the total duration corresponds to $49.4 \%$ of the total rainfall. For events of 6-12 hours, 12-24 hours, and over 24 hours, these values are, respectively, $29.5 \%, 20.4 \%$, and $17.2 \%$. This shows a significant variation in temporal rainfall distribution according to rainfall duration.

DNIT (2005) states that for events less than 12 hours, the rainfall peak is usually observed in the first half of the total duration, which is not the case in most of the longer-lasting storms. In the case of Florianópolis city, for rainfall events up to 6 hours, the first half of the duration accounts for $87.1 \%$ of the total rainfall. For rainfall events of 6-12 hours and 12-24 hours, the first half of the duration accounts for $79 \%$ and $63.9 \%$ of the total rainfall, respectively. For rainfall events over 24 hours, there is a more uniform distribution, with $50 \%$ of the total rainfall in the first half of the duration and $50 \%$ in the second half.

Furthermore, Powell et al. (2007) question the use of Huff curves established without defining the duration. According to these authors, its use for other durations assumes that events of any duration have the same pattern of temporal distribution, highlighting that the validity of this assumption is questionable, as it is widely believed that short and long duration events behave differently.

Thus, rainfall duration is important in the definition of the design hyetograph. The curves established by Huff (1967) were not differentiated by duration. In turn, SCS (1986) and Wisner (1970) showed different temporal variation curves according to rainfall duration. 


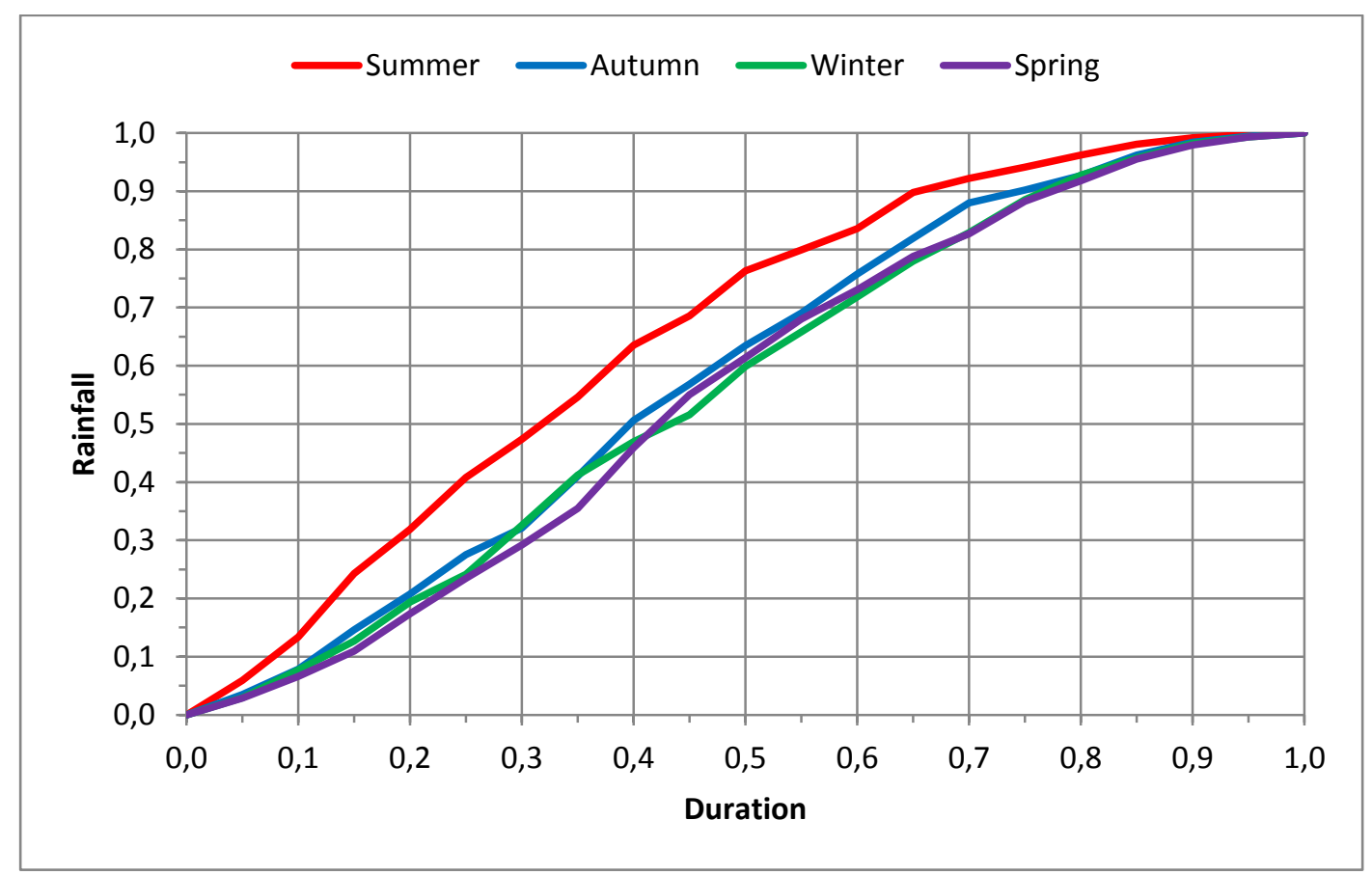

Figure 7 - Pattern of temporal rainfall distribution with $50 \%$ probability, by season, for Florianópolis city (SC).

Table 5 shows the accumulated rainfall values (\%) as a function of duration (\%) for rainfall events with $50 \%$ probability (P50) according to the rainfall types defined by Huff (1967) and the duration range. In this way, by considering rainfall duration, the designer can select the design hyetograph more appropriately. Application of these data in the estimation of the design rainfall hyetrograph allows obtaining more representative local values for the region of Florianópolis city, Santa Catarina State. 
Table 5 - Pattern of temporal rainfall distribution with $50 \%$ probability, by rainfall duration, in Florianópolis city, Santa Catarina State.

\begin{tabular}{ccccccccc}
\hline \multirow{2}{*}{$\begin{array}{c}\text { Duration } \\
(\%)\end{array}$} & \multicolumn{9}{c}{ Rainfall type } \\
\cline { 2 - 9 } & Type I & Type II & Type III & Type IV & $<6 \mathrm{~h}$ & $6-12 \mathrm{~h}$ & $12-24 \mathrm{~h}$ & $>24 \mathrm{~h}$ \\
\hline 5 & 13.9 & 2.1 & 2.1 & 1.4 & 10.8 & 4.2 & 4.2 & 3.0 \\
10 & 33.6 & 5.2 & 3.3 & 2.7 & 24.6 & 9.5 & 8.4 & 7.1 \\
15 & 46.6 & 8.1 & 5.0 & 5.5 & 38.5 & 23.3 & 13.9 & 10.8 \\
20 & 58.2 & 12.0 & 6.5 & 8.3 & 49.4 & 29.5 & 20.4 & 17.2 \\
25 & 66.6 & 16.8 & 7.7 & 10.8 & 62.8 & 38.3 & 26.4 & 23.4 \\
30 & 73.9 & 25.8 & 10.5 & 13.7 & 70.1 & 47.6 & 33.3 & 28.7 \\
35 & 78.4 & 35.4 & 12.0 & 14.7 & 75.2 & 57.8 & 41.4 & 33.8 \\
40 & 80.9 & 46.9 & 13.5 & 16.6 & 80.8 & 64.5 & 50.7 & 40.3 \\
45 & 84.8 & 56.0 & 17.9 & 21.5 & 82.6 & 72.1 & 55.6 & 44.0 \\
50 & 87.2 & 65.2 & 22.3 & 25.4 & 87.1 & 79.0 & 63.9 & 50.3 \\
55 & 89.5 & 74.2 & 29.5 & 27.9 & 91.1 & 82.3 & 68.6 & 60.9 \\
60 & 91.6 & 80.6 & 40.8 & 32.9 & 93.0 & 87.4 & 78.3 & 65.1 \\
65 & 93.1 & 85.9 & 59.3 & 35.2 & 94.7 & 92.4 & 83.1 & 74.4 \\
70 & 94.9 & 90.7 & 76.2 & 41.4 & 96.2 & 93.7 & 87.1 & 80.7 \\
75 & 96.1 & 93.2 & 86.9 & 47.2 & 97.4 & 95.6 & 90.8 & 85.1 \\
80 & 97.2 & 95.3 & 92.4 & 55.4 & 97.9 & 96.9 & 93.4 & 90.7 \\
85 & 98.5 & 97.0 & 95.9 & 71.3 & 98.5 & 98.3 & 95.8 & 95.3 \\
90 & 99.3 & 98.9 & 98.6 & 85.1 & 99.1 & 99.2 & 97.9 & 98.0 \\
95 & 99.7 & 99.6 & 99.6 & 96.0 & 99.6 & 99.6 & 99.5 & 99.4 \\
100 & 100.0 & 100.0 & 100.0 & 100.0 & 100.0 & 100.0 & 100.0 & 100.0 \\
\hline & & & & & & & &
\end{tabular}

Figure 8 shows the frequencies of maximum rainfall events in the different duration intervals. It is observed that $15.4 \%$ of the analyzed heavy rainfall events occur in the range of 0 to $5 \%$ of the duration, whereas the range of 95 to $100 \%$ of the duration accounts for only $2.05 \%$ of these events. This shows the asymmetry of the distribution, indicating that the advance coefficient is less than 0.5 . 


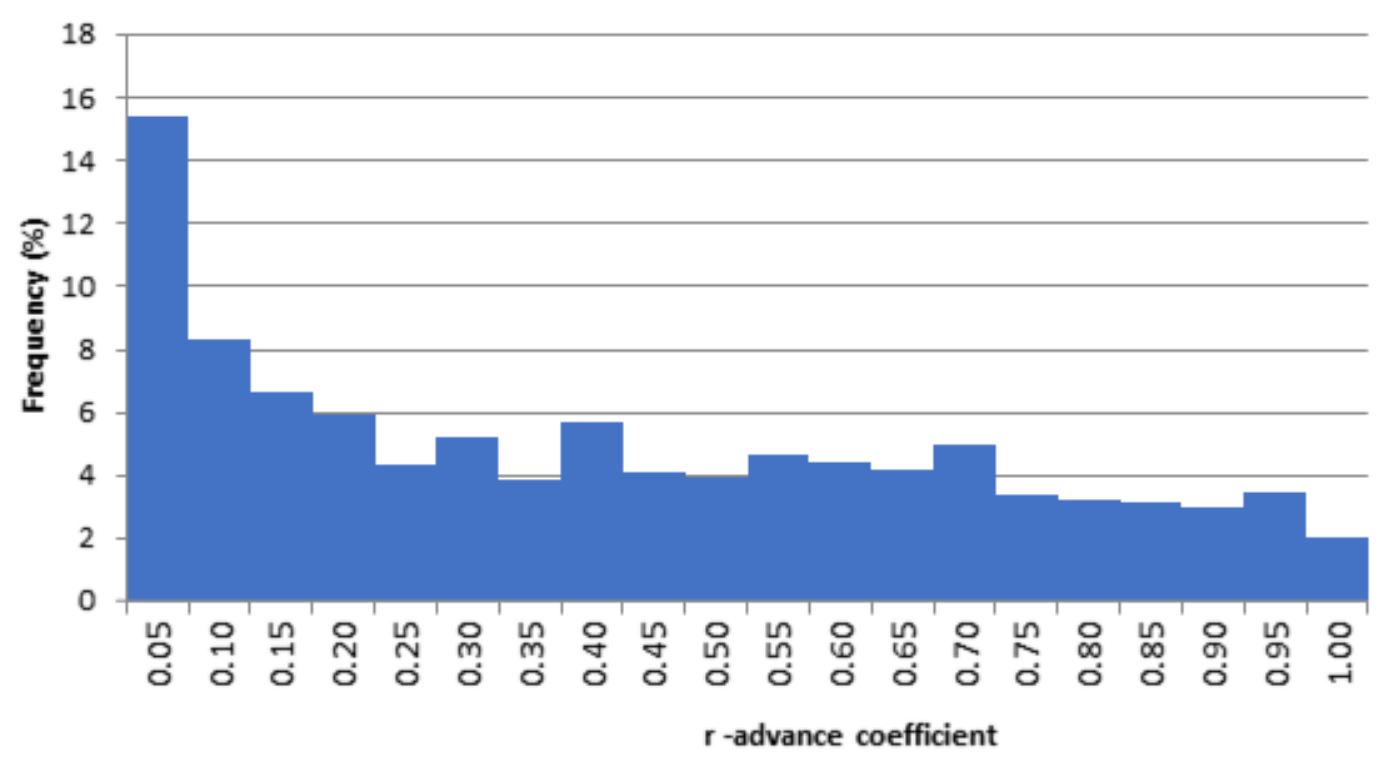

Figure 8- Frequencies of maximum rainfall events in the different duration intervals for Florianópolis city, Santa Catarina State.

Table 6 shows the average values of the advance coefficient for Florianópolis city to be applied in the preparation of the hyetograph by the Chicago method. For Florianópolis city, the average advance coefficient was 0.389. In Brazil, there are limited studies addressing local values of the advance coefficient. Tucci (2012) cites an advance coefficient of 0.44 for Porto Alegre city and 0.36 for São Paulo city, without indicating any further details of the data period used. Chow et al. (1988) cite advance coefficients ranging from 0.294 to 0.48 for different locations in the USA.

Table 6 - Advance coefficient of rainfall events in Florianólis city (SC).

\begin{tabular}{lccccc}
\hline & \multicolumn{5}{c}{ Rainfall duration classes } \\
\cline { 2 - 6 } Season & $<6 \mathrm{~h}$ & $6-12 \mathrm{~h}$ & $12-24 \mathrm{~h}$ & $>24 \mathrm{~h}$ & Total \\
\hline Summer & 0.235 & 0.286 & 0.366 & 0.451 & 0.339 \\
Autumn & 0.223 & 0.306 & 0.382 & 0.476 & 0.386 \\
Winter & 0.188 & 0.402 & 0.401 & 0.505 & 0.429 \\
Spring & 0.290 & 0.354 & 0.440 & 0.504 & 0.428 \\
\hline Total & 0.238 & 0.322 & 0.399 & 0.484 & 0.389 \\
\hline
\end{tabular}

For Florianópolis city, the advance coefficient varies largely as a function of rainfall duration. For rainfall events less than 6 hours, the advance coefficient is 0.238 ; for rainfall events over 24 hours, the advance coefficient is 0.484 . Likewise, lower values are observed in the summer, averaging 0.338 ; in the autumn, the advance coefficient is 0.389 . In winter and spring, the values are approximately equal to 0.43 , and rainfall events over 24 hours in these seasons have a delay coefficient of around 0.5 , indicating that the peak occurs in the middle of the event. In these cases, the hyetograph approaches a triangular or alternating block shape. 
The determination of the advance coefficient is important in the preparation of the hyetograph, since it allows to establish a more realistic shape according to the rainfall events observed in the studied site. In the case of Florianópolis city, using the advance coefficient in the preparation of the hyetograph for short rainfall events should lead to better results than using alternating block or triangular hyetographs.

\section{CONCLUSION}

Based on the analysis of rainfall data from Florianópolis city, Santa Catarina State, the following conclusions can be drawn:

1) The most frequent heavy rainfall events are type I $(39.9 \%)$, followed by type II $(31.0 \%)$, type III $(15.7 \%)$, and type IV $(13.5 \%)$;

2) Heavy rainfall events are more frequent in the summer (35.5\%) and spring $(26.4 \%)$, and less frequent in the autumn $(17.5 \%)$;

3) Rainfall events less than 12 hours predominate in the summer, and longer events have a uniform seasonal distribution;

4) The temporal distribution of heavy rainfall events differs in the summer, with higher concentration at the beginning of events;

5) Marked differences were observed in the temporal distribution curves of rainfall events of different durations, in which shorter rainfall events have a more advanced distribution;

6) The average advance coefficient was 0.385 , varying largely as a function of rainfall duration. Rainfall events less than 6 hours have an advance coefficient of 0.238 , and rainfall events over 24 hours have an advance coefficient of 0.484 .

\section{REFERENCES}

ABREU, F. G.; ANGELINI SOBRINHA, L.; BRANDÃO, J. L. B. Análise da distribuição temporal das chuvas em eventos hidrológicos extremos. Engenharia Sanitária e Ambiental, v. 22, n.2, p. 239-250, 2017.

ABREU, E. C. F.; BELLO, I. P.; OLIVEIRA, L. F. C.; FRANCO, C. S. Hietogramas obtidos a partir de relações IDF para as Mesoregiões Sul/Sudeste e Campo das Vertentes, MG. Sustentare, v. 2, n. 2, p.1-15, 2018.

ALVARES, C. A.; STAPE, J. L.; SENTELHAS,P. C.; MORAES GONÇALVES, J. L.; SPAROVEK, G. Köppen's climate classification map for Brazil. Meteorologische Zeitschrif, v. 22, n. 6, p.711-728, 2013.

ANDRADE, K. M. Climatologia e Comportamento dos Sistemas Frontais Sobre a América do Sul. Dissertação de Mestrado em Meteorologia, Instituto Nacional de Pesquisas Espaciais, São José dos Campos, 79 p, 2005.

AZLI, M.; RAO, A. R. Development of Huff curves for Peninsular Malaysia. Journal of Hydrology, Denver, 83, v. 4, p. 77-84. 2010.

BACK, Á. J.; POLETO, C. Análise de chuvas erosivas. In: Poleto, C (Ed.). Bacias hidrográficas: Modelos e ferramentas. GFM Gráfica \& Editora, 143- 174. 2019. 
BACK, Á. J. Distribuição temporal de chuvas intensas de Caçador, SC. In: XXXVIII Congresso Brasileiro de Engenharia Agrícola [CD-ROM]. Juazeiro: SBEA. 2010.

BACK, Á. J. Time distribution of heavy rainfall events in Urussanga, Santa Catarina State, Brazil. Acta Scientiarum Agronomy, v. 33, n.4, p. 583-588, 2011.

BACK, Á. J.; SÔNEGO, M.; POLA, A. C. Distribuição temporal de chuvas intensas de Chapecó, SC In: XXI Simpósio Brasileiro de Recursos Hídricos, Brasília: ABRH, 2015.

BEZAK, N.; SRAJ, M.; RUSJAN, S.; MIKOS, M. Impact of the Rainfall Duration and Temporal Rainfall Distribution Defined Using the Huff Curves on the Hydraulic Flood Modelling Results. Geosciences, v.8, n.69, 2018.

CANHOLI, A. P. Drenagem urbana e controle de enchentes. São Paulo: Oficina de Textos. 2005. 302 p.

CARDOSO, C. S. Abrangência e persistência de eventos extremos de precipitação no Sul do Brasil: El Niño Oscilação Sul e padrões atmosféricos. Tese Doutorado. Florianópolis: FFLCH/UFSC. 2017.113 p.

CAVALCANTI, I. F. A.; KOUSKY, V. E. Frentes frias sobre o Brasil. In: CAVALCANTI, I.F.A.; FERREIRA, N.J.; SILVA DIAS, M.A.F.; JUSTI DA SILVA, M.G.A. (org.). Tempo e Clima no Brasil. Oficina de Textos, São Paulo, p. 135$147,2009$.

CHOI, S.; JOO, K.; SHIN, H.; HEO, J. H. Improvement of Huff's method considering severe rainstorm events. Journal of Korea Water Resources Association, v. 47, n. 11, p. 985-996, 2014

CHOW V.T.; MAIDMENT, D. R.; Mays, L. W. Applied hydrology. New York: McGraw-Hill. 1988.

CRUCIANI, D. E.; MACHADO, R. E.; SENTELHAS, P. C. Modelos da distribuição temporal de chuvas intensas em Piracicaba, SP. Revista Brasileira de Engenharia Agrícola e Ambiental, v. 6, n. 1, p. 76-82, 2002.

DIAS, É. C.; PENNER, G. C. Contabilização de Equações de IntensidadeDuração-Frequência Disponíveis no Brasil. Anuário do Instituto de Geociências UFRJ, 42, p. 209-216, 2019.

DNIT - Departamento Nacional de Infraestrutura de Transportes. Manual de Hidrologia básica para Estruturas de Drenagem. Rio de Janeiro. 2005. 133p.

EL- SAYED, E. A. H. Development of synthetic rainfall distribution curves for Sinai area. Ain Shams Engineering Journal, v. 9, p. 1949-1957, 2018.

ESCOBAR, G. C. J.; SELUCHI, M. E.; ANDRADE, K. Classificação Sinótica de Frentes Frias Associadas a Chuvas Extremas no Leste de Santa Catarina (SC). Revista Brasileira de Meteorologia, São Paulo, v. 31, n. 4, supl. 1, p. 649-661, Dec. 2016

EVANGELISTA, A. W. P.; CORRECHEL, V.; ARANTES, N. R. M.; ALVES JÚNIOR, J.; CASAROLI, D. Padrões hidrológicos e período de retorno das chuvas erosivas de Goiânia-GO. Global Science and Technology, v. 9, n. 2, p. 1-12, 2016. 
Empresa de Pesquisa Agropecuária e Extensão Rural de Santa Catarina-Epagri. Zoneamento Agroecológico e Socioeconômico do Estado de Santa Catarina, Epagri. (CD),1999.

EWEA, H. A.; ELFEKI, A. M. M.; BAHRAWI, J. A.; AL-AMRI, N. S. Sensitivity analysis of runoff hydrographs due to temporal rainfall patterns in Makkah AlMukkramah region, Saudi Arabia. Arabian Journal of Geosciences Springer, v. 9, n. 5, 424, 2016.

GHASSABI, Z.; KAMALI, G. A.; MESHKATTE, A. H.; HAJAM, S.; JACAHERI, N. Time distribution of heavy rainfall events in south west of Iran. Journal of atmospheric and Solar-Terrestrial Physics, v. 145, p. 3-60, 2016.

GRIMM, A. M. Clima da Região Sul do Brasil. In: Tempo e Clima no Brasil. Cavalcanti, I. F. A., N. J. Ferreira, M. G. Justi da Silva, M. A. F. Silva Dias (Eds.), Oficina de Textos, São Paulo, Capítulo v. 17, p. 259-275, 2009.

GRIMM, A. M.; FERRAZ, S. E. T.; GOMES, J. Precipitation anomalies in Southern Brazil associated with El Niño and La Niña events. J. Climate, AMS, v. 11, n.11, p. 2863-2880, 1998.

HERRMANN, M. L. de P. (Org.) Atlas de Desastres Naturais de Santa Catarina. 10. ed. Florianópolis, SEA/DEGED-CopyLlaser Gráfica Digital, 2007. 148p.

HUFF, F. A. Time distribution of rainfall in heavy storms. Water Resources Research, v. 3, n. 4, p.1007-1019, 1967.

HUFF, F. A. Time Distributions of Heavy Rainstorms in Illinois ISWS/CIR-173/90 Circular 173 State of Illinois Department of Energy and Natural Resources, 1990. 22p.

MARCELLINI, S. S. Análise de critérios para determinação de tormentas de projeto e sua influência nos hidrogramas em pequenas bacias hidrográficas. Dissertação (Mestrado em Engenharia Civil) - Escola Politécnica da USP, São Paulo. 1994. 176p.

MOLIN, L.; DEVILLA, I.; GOULART, J. P.; MAESTRINI, A. P. Distribuição temporal de chuvas intensas em Pelotas, RS. Revista Brasileira de Recursos Hídricos, v.1, n.2, p. 45-51, 1996.

MONTEIRO, L. R., KOBIYAMA, M. Influências da distribuição temporal de precipitação no mapeamento de inundação. REGA, v. 11, n. 2, p.25-35, 2014.

NA, W.; YOO, C. Evaluation of Rainfall Temporal Distribution Models with Annual Maximum Rainfall Events in Seoul, Korea. Water, v.10, 1468, 2018.

NIMER, E. Clima. In: Geografia do Brasil: Região Sul. Série Recursos Naturais e Meio Ambiente. 4, Rio de Janeiro: IBGE, 151-187, 1979.

OCCHIPINTI, A. G. H.HIDROMETEOROLOGIA. In: Ramos, F.; OCCHIPINTI, A. G., VILLA NOVA, N. A., REICHARDT, K. Engenharia Hidrológica. Rio de Janeiro: UFRJ, p. 20-141, 1989.

PAN, C.; WANG, X.; LIU, L.; HUANG, H.; WANG, D. Improvement to the Huff curve for design storms and urban flooding simulations In Guanzhou, China. Water Multidisciplinary Digital Publishing Institute, v.9, n. 6, 411, 2017. 
PEREIRA, D. C.; DUARTE, L. R.; SARMENTO, A. P. Intensity-duration-frequency curves determination of Ipameri - Goiás. Revista Eletrônica de Engenharia Civil, v. 13, n. 2, p.233-246, 2017.

POWELL, D. N.; KHAN, A. A.; AZIZ, N. M.; RAIFORD, J. P. Dimensionless Rainfall Patterns for South Carolina. Journal of Hydrologic Engineering, v. 12, p.130133, 2007.

PRODANOVIC, P.; SIMONOVIC, S.P. Generation of synthetic design storms for the Upper Thames River Basin. Water Resources Reseach Report, Report 4, 2004. 20p.

RODRIGUES, M. L. G. Eventos de chuva orográfica em Santa Catarina: Climatologia e simulações numéricas. Tese Doutorado. São Paulo: IAG/USP. 2015. $113 \mathrm{p}$.

RODRIGUES, M. L. G.; FRANCO, D.; SUGAHARA S. Climatologia de frentes frias no Litoral de Santa Catarina. Rev. Bras. Geofís., v. 22, n. 2, p. 135-151, 2004.

RODRIGUES, M. L. G., YNOUE, R. Y. Mesoscale and synoptic environment in three orographically-enhanced rain events on the coast of Santa Catarina (Brazil). Weather and Forecasting, Boston, v.31, n. 5, p. 1529-1546, 2016.

RODRIGUES, M. L. G.; YNOUE, R.; ALVES, M. P. Episódios de chuva intensa na região da grande Florianópolis/SC: análise preliminar dos eventos e caracterização sinótica. In: IV Simpósio Internacional de Climatologia, João Pessoa: SBMet, 2011.

SANTOS, T. E. M DO; MONTENEGRO, A. A. A. Erosividade e padrões hidrológicos de precipitação no Agreste Central Pernambucano. Revista Brasileira de Engenharia Agrícola e Ambiental, v. 16, n. 8, p.871-880, 2012.

São Paulo. Secretaria Municipal de Desenvolvimento Urbano. Manual de drenagem e manejo de águas pluviais: aspectos tecnológicos: diretrizes para projetos. São Paulo: SMDU. 2012.130 p.

SENTELHAS, P. C.; CRUCIANI, D. E.; PEREIRA, A. S.; VILlA NOVA, N. A. Distribuição Horária de Chuvas Intensas de Curta Duração: um subsídio ao dimensionamento de projetos de drenagem superficial. Revista Brasileira de Meteorologia, v. 13, n.1, p. 45-52, 1998.

SEVERO, D. L. Estudo de Casos de Chuvas Intensas no Estado de Santa Catarina. Dissertação de Mestrado, Instituto Nacional de Pesquisas Espaciais, São José dos Campos, 1994.

SCS. Soil Conservation Service. (1976). Earth dams and reservoirs. Washington U.S. Govt Print Off. (Technical Release, 60).

SILVEIRA, A. L. Cumulative equations for continuous time Chicago hyetograph. Brazilian Journal of Water Resources, v. 21, n. 3, p. 646-651, 2016.

TEIXEIRA, M. S.; SATYAMURTY, P. Dynamical and Synoptic Characteristics of Heavy Rainfall Episodes in Southern Brazil. Mon. Wea. Rev., v. 135, p.598-617, 2007.

TUCCI, C. E. M. Hidrologia - Ciência e Aplicação. Porto Alegre. Editora da Universidade. ABRH. 2012. 943p. 
U.S. Department of Agriculture Soil Conservation Service. National Resources Conservation Service, Conservation Engineering Division. Urban hydrology for small watersheds. Technical release TR-55.1986.

WEESAKUL, U.; CHAOWIWAT, W.; REHAN, M. M.; WEESAKUL, S. Modification of a design storm pattern for urban drainage systems considering the impact of climate change. Engineering and Applied Science Research, v. 44, n. 3, p.161169, 2017.

WIESNER, C. J. Hydrometeorology. London: Chapman and Hall. 1970. 232p.

WISCHMEIER, W. H., SMITH, D. D. Rainfall energy and its relationship to soil loss. Trans. Am. Geophys Union, v. 39, p.285-91, 1958.

YIN, S. Q.; XIE, Y.; NEARING, M. A.; GUO, W. I.; ZHU, Z. Intra-storm temporal patterns of rainfall in China using Huff curves. Transactions of the ASAE, v. 59, n. 6, p. 1619-1632, 2016.

ZAHED FILHO, K.; MARCELLINI, S. S. Precipitações máximas. In: Tucci, C. E. M., Porto, R. L. L., Barros, M. T. Drenagem Urbana. Porto Alegre: ABRH. Editora da Universidade. 1995. 